
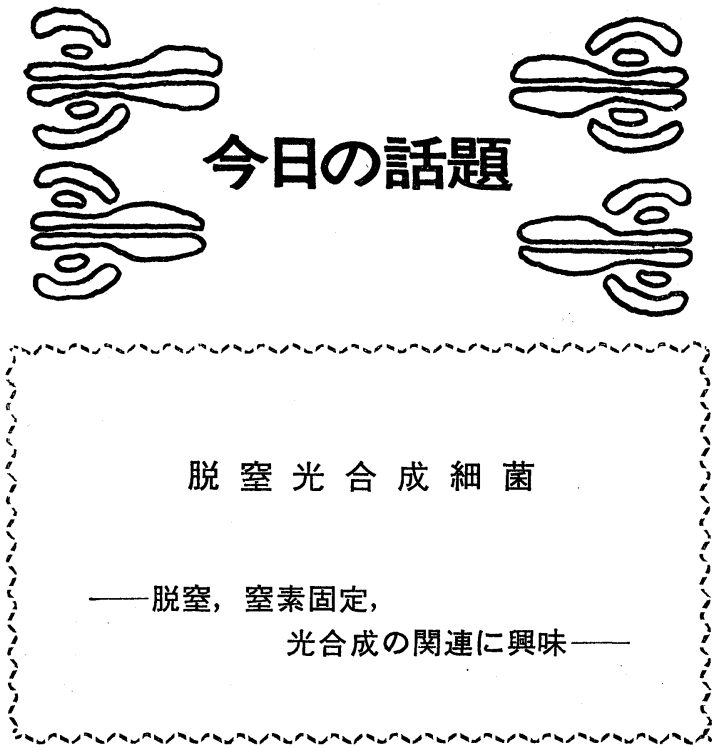

光合成細菌は，光エネルギーを利用して光合成的に生 育できる原核微生物である. しかし，水を電子供与体と する酸素発生系（光合成系I）をもたず，この点でラン 藻とは区別される. 光合成細菌は大別して，紅色無イオ ウ細菌（Rhodospirillaceae），紅色イオウ細菌（Chromatiaceae), 緑色イオウ細菌 (Chlorobiaceae) 飞分類さ れる. 紅色, 緑色イオウ細菌は, 主に $\mathrm{H}_{2}$, 無機イオウ 化合物を電子供与体として光合成的に, 自養的（photolithotrophic）飞生育し，酸素呼吸では生育できない。 一方，紅色無イオウ細菌は， $\mathrm{H}_{2}$ の他は，主に糖，有機酸， アルコールなどの有機化合物を電子供与体および炭素源 として利用し，光合成的 (photoheterotrophic) そまたは 一般的に酸素呼吸で，他養的 [(chemo) heterotrophic] に生育する．紅色無イオウ細菌の中でる，酸素に対する 適応性が高いものほど, 他養性の度合いが高い，紅色， 緑色イオウ細菌は生育因子の要求性はみられず，まった く自養的であるが，紅色無イオウ細菌はビオテンなどを 要求し,この面においても他養的光合成細菌である.

脱窒とは，嫌気条件で酸素の代りに硝酸，亜硝酸を終 末電子受容体として利用し， $\mathrm{N}_{2}, \mathrm{~N}_{2} \mathrm{O}$ を放出する現象で ある.これは大腸菌にみられるような硝酸を還元して亜 硝酸を生成する “硝酸呼吸” の特殊な形式と考兄られる. このような脱窒を行なら菌は多くの属にわたって知られ て抢り(1)，いずれも通性嫌気性細菌である。また， Thiobacillus denitrificans を除けば，いずれも從属栄 養細菌である.以下に述べる脱窒光合成細菌もこの範ち
ゅらには入るが，これまで光合成能を有する脱窒菌は見 いだされていなかった．硝酸還元といら点では，嫌気性 細菌 Clostridium perfringens にみられるように, フ ェレドキシンを值接の電子供給体として硝酸を亚硝酸に する “硝酸発酵”が知られて和り，これは進化的に硝酸 呼吸の一段階前の形式である(2). 脱窒を含めた硝酸呼吸 系は, 酸素呼吸系と類似した電子伝達系より成り，とれ と共役した酸化的リン酸化が行なわれる.

近年, 光合成細菌を利用して廃水を浄化し，同時に菌 体を利用しようといら研究がすすめられて抢り，また廃 水処理に括いて, 窒素の除去に脱窒菌が重要な役割を果 たしている．筆者らは長野県飯田市の凍豆腐廃水処理施 設のラグーンが赤色を帯び, 余剩污泥が非常に少ないこ とを聞き，このラグーンに脱窒光合成細菌の存在を予想 して調査した結果，3株を分離することができた。この ラグーンでは, photoheterotroph としての光合成細菌 数が全従属栄養細菌の $2.5 \%$ であった（星野，私信).

分離した菌は，その形態，有機化合物の利用性，光合 成器官クロマトフォアの形状, カロチノイド色素の種類, 生育因子の要求性，核酸塩基組成，また酸素呼吸でよく 生育し，イオウ化合物を利用しないことなどから，紅色 無イオウ細菌で, Rhodopseudomonas sphaeroides に近 似するが，特に脱窒によって嫌気的条件で暗所でも生育 することから，R. sphaeroides forma sp. denitrificans と命名した(3).

光合成細菌による脱窒で興味深い問題は, エネルギー 獲得系として脱窒と光合成がどのような相互作用をして いるかである，そこで，種々の条件で生育させたときの doubling timeを調べたところ，硝酸存在下で，脱窒 光合成培養すると, 光合成培養に比べて生育が 2 倍以上 よくなることがわかった（表)．この際， $1 l$ 培養当り 2 日で約 $140 \mathrm{~m} 1$ の窒素ガスが放出された.この菌は硝酸 の同化はしないが，通常の光合成細菌と同様に光エネル ギーを利用して窒素固定をする．窒素固定能と脱窒能を もった細菌はこれが初めてと考兄られるが，最近，Spirillum lipoferum も両者の能力をるつことが示されてい る(4). 光窒素固定培養したときに硝酸添加によって生育 が抑制される事実は，今後窒素固定と脱窒との関係を調 べる上で興味深い。

次に，脱窒光合成培養した菌の細胞懸濁液を用い，He 
種々の培養条件*における doubling time $(\mathrm{hr})$

\begin{tabular}{ll|ll}
\hline 嫌気・明 & 嫌気 $\cdot$ 暗 & \\
$\mathrm{NH}_{4}{ }^{+}$ & 26 & $\mathrm{NH}_{4}{ }^{+}$ & no growth \\
$\mathrm{NH}_{4}{ }^{+}+\mathrm{NO}_{3}{ }^{-}$ & 11 & $\mathrm{NH}_{4}{ }^{+}+\mathrm{NO}_{3}{ }^{-}$ & 20 \\
$\mathrm{NO}_{3}{ }^{-}$ & no growth & 好気・暗 & \\
$\mathrm{N}_{2}$ & 21 & $\mathrm{NH}_{4}{ }^{+}$ & 3.3 \\
$\mathrm{~N}_{2}+\mathrm{NO}_{3}{ }^{-}$ & 155 & $\mathrm{NO}_{3}^{-}$ & no growth
\end{tabular}

* 炭素源はりんご酸とし, $\mathrm{N}$-源を含まない無機培地に $\mathrm{NH}_{4}{ }^{+}$ または $\mathrm{NO}_{3}^{-}$を加えた. $\mathrm{N}_{2}$ は気相を窒素で置換した。

ガス下ワールブルグマノメーターで，脱窒活性を測定し， 脱窒に対する光の影響を調べたところ，リンゴ酸を電子 供与体とした場合, 対数期の菌では光は脱窒にほとんど 影響しないが，定常期の菌の脱窒は暗ではほとんど行な われず, 光照射によって強く促進された. この定常期の 菌を用い, 電子供与体を種々変えて脱窒に対する光の影 響を調べたところ，グルコースや乳酸では暗で脱窒が起 こり，光照射によってほぼ $100 \%$ 阻害され，再び暗にす ると脱窒は回復した.この脱窒は光照射の on-off に可 逆的に対応した. 一方，コハク酸，リンゴ酸では，前述 のように暗では脱窒がほとんど起こらず，光照射によっ て強く促進されるが, 一度促進された脱窒は, 次に暗に しても促進されたままで非可逆的である.

以上の結果をまとめると, (1)光により阻害される暗脱 窒, (2)光照射により強く促進される光活性化脱窒, (3)光 に無関係な脱窒, の 3 つが観察される.グルコースある いは乳酸を電子供与体としたときの光阻害については, 細胞懸濁液めるいはクロマトフォアの酸素吸収が光照射 で阻害されるといら類似した現象が知られている. 乳酸 を電子供与体としたときの暗脱窒は， $\mathrm{NADH}$ 脱水素酵 素の阻害剤であるロテノンやアミタールで阻害される.

光合成細菌に拈ける NAD の還元は, 光またはエネル ギー依存の電子の逆流によることが知られて和り，また この暗脱窒が脱共役剤のグラミシジンDにより逆に活性 化されたことから，この光阻害は $\mathrm{NADH}$ から硝酸に至 る電子伝達系において, 光によって電子が逆流するため そ考えられる.

コハク酸あるいはリンゴ酸を電子供与体としたときの 光活性化脱窒は, まだ未解決である.コハク酸からは電 子が直接電子伝達系に入るが，この光-コハク酸脱窒は， アンティマイシンAや HQNO* のようなチトクローム

HQNO : nonylhydroxyquinoline $\mathrm{N}$-oxide $b$ 酸化阻害剂あるいは脱共役斉に対して，暗脱窒に比べ て感受性が高い.また，この光活性化が非可逆的である ことから、コハク酸のとり达みが光依存性であるとも推 定される.この光活性化脱窒とともに，硝酸還元の電子 伝達系年のもの，およびそれが光合成のサイクリック電 子伝達系とどのような関連をもっているかは，今後の興 味ある問題である.

最近, エネルギー獲得代謝の進化といら問題において, 硝酸呼吸のような無酸素呼吸系と光合成系のどちらが早 く出現したかについて論争がなされている(5).この意味 で,この光合成細菌が重要な位置にあることが推定され るが, 脱窒酵素系, 脱窒と光合成の電子伝達系, 脱窒と 窒素固定の関連などを生化学的に明らかにしていくこと により,この問題解決に一つの杀口を与えることが期待 される.

1) W. J. Payne : Bact. Rev., 37, 409 (1973).

2) 江上不二夫 : サイェンス, 3, 72 (1973).

3) T. Satoh, Y. Hoshino \& H. Kitamura: Arch. Microbiol., 108, 265 (1976).

4) C. A. Neyra, J. Döbereiner, R. Lalande \& R. Knowles: Can. J.Microbiol., 23, 300 (1977).

5) 桶口昌孝 : 生化学, 49, 329 (1977).

（佐藤 敏生, 東京都立大学理学部)

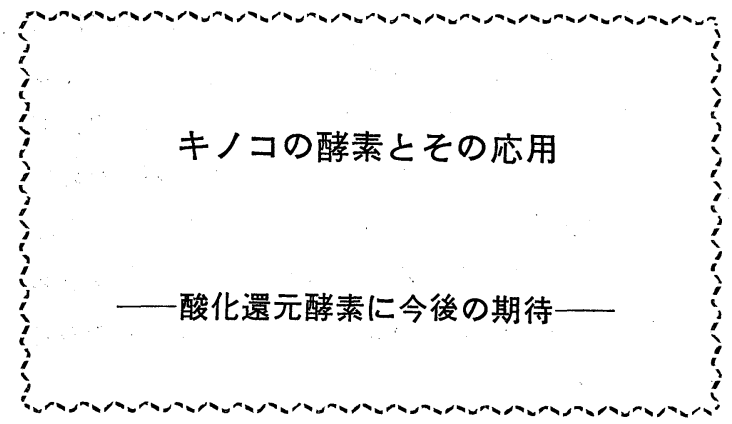

キノコといえば，何か摩訶不思議な力を期待させる存 在である. そのためか, キノコの成分や醊酵産物に関す る関心が高まりつつある，しかし，現在までのところ， キノコに特徵的な物質で, しかも有用性が高いというも のは発見されていないようである.

マッタケ目のキノコには, 特異な幻覚物質や toxin 生成するものがあるし，キノコは一般に，他の微生物に あまりみられない polyacetylene, terpenoid などを生 成する(1,2)。この中には抗生物質として記載されている ものも多いが，残念ながら感染症の治療薬として使用さ れているものはない(3)。このような事情はキノコの酵素 
についても大体当てはまるようである.キノコは, 他の 微生物で生成の認められている酵素は大抵生成するし, その中には産業的規模で生産されている例もあるが，個 個の酵素に注目してみれば, 細菌やカビの中にそれぞれ のより強力な生産者を見つけることができる. したがっ て, キノコの酵素に特徽的な面を求めるとすれば, キノ コがリグニン分解に大きな役割を果たしている点に求め るべきであろう.

微生物は生態的には還元者であり, その強力な加水分 解作用は早くから注目されてきた. キノコの場合もとの 例に洩れず，菌体外に生成される加水分解酵素がまず研 究の対象となった(4).

プロテアーゼをみると, ウスバタケ，ヒイロタケ，ツ ガサルノコシカケなどのものが詳しく研究されており, これらは凝乳活性が高い点でも注目される.一般に，キ ノコのプロテアーゼは acid proteinase であるが, ウシ グソヒトヨタケの生成するアルカリプロテアーゼにはカ ラゲニン脬腫を抑制する性質があり，ブラジキニン分解 力が高いことが知られている.

白絹病菌は耐酸性の加水分解酵素群を生成して扣り ${ }^{(5)}$, ウスバタケ, ヒイロタケも酸性域で活性の高い加水分解 酵素群の生産性が高い(4).これらの酵素群については, 植物組織の崩壊活性が高いところから, 果汁清澄, ミカ ン内果皮の䟝皮，大豆の除皮，細胞含有成分の抽出など， 食品加工への応用が検討された. 特に，ウスバタケの酵 素はパイナップルの繊維を精練して良質の民芸的風合の 緎維を作るのに用いられるし，植物細胞のプロトプラス ト化にも広く用いられている. 飼料添加酵素としての効 果も大さい.

植物組織の崩壊は, 一般に pectinlyase によるものと されるが，白絹病菌やウスバタケの場合は endo PG (endo 型ポリガラクチュロナーゼ）によるものと思われ る. オッネンタケモドキ属が PTE（ペクチントランス エリミナーゼ）を生成するといら公開特許があるが，学 術誌で見るかぎりでは PTE の報告はまだない.キノコ のペクチナーゼは endo PG が主体である. しかし， 飼 料添加酵素のような場合は, 単に endo PGのみならず, セルラーゼ, ヘミセルラーゼ, プロテアーゼなどの複合 作用による効果が大きいのであろう.

生酵母の分解は endo 型の lytic glucanaseによって
起こる.しかし，キノコでこの種の酵素を生成している 例は馬田らの報告 ${ }^{(6)}$ にあるくらいで数少なく大抵は exo 型である. もっとも, exo 型の glucanase の中には, メルカプトエタノールや phosphomannanase のような PR-factor 処理や加熱処理をした酵母を分解するものが ある. コキララタケの $\beta-1,3$-glucanase もこの例であ る.

キノコのセルラーゼに関する報告はきわめて多い.セ ルラーゼは多成分系であり，その作用機作に関する考え 方はかなり混乱していたが，最近ようやく明白になって きたようである，セルラーゼには，結局，非結晶領域を ランダムに切断する CMCase と, 結晶領域を exowise に近い型で切断する Avicelase があり，両者の相 剰効果で繊維質がよく分解されるのである. しかし，七 ルラーゼの多くは䋐維質に作用してオリゴ糖を遊離する が，グルコースを遊離することが少ない。

今後の科学技術の動向として, 資源再利用や公害防止 が大きなテーマとなるが，この点から見て，緘維素源の 糖化は恰好の題材であろら．アメリカを中心として，す でに莫大な研究が開始されている．しかし，その主役は トリコデルマのセルラーゼであって，キノコのものでは ない. キノコのセルラーゼの中から, トリコデルマのも のに替るものが現われるためには, “gluco-cellulase” といった糖化力の高いセルラーゼの発見に期待せねばな らない。

セルラーゼに関して興味深いことは，セルラーゼ作用 とラッカーゼ作用の共役関係である(7) (図). white rot fungi のもつ CQORase（セロビオースキノンオキシド レダクターゼ）とラッカーゼは図に示すように共役して いる. したがって，セルラーゼによって生じたセロビオ ースが CQORase で酸化されれば， ラッカーゼによっ て生じたフェノールの酸化物は還元され，酸化物がリグ

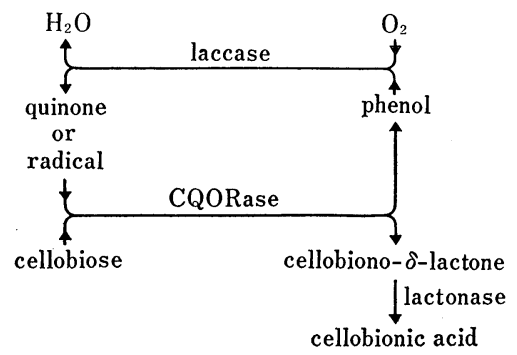

CQORase とラッカーゼの共役関係 
ニンに再合成されるのを妨げることになる. セルラーゼ が間接的にリグニン分解に役立っている可能性が示唆さ れたのである. brown rot fungi を用いた研究でも, $\mathrm{H}_{2} \mathrm{O}_{2}+\mathrm{Fe}^{2+}$ 系と共役させることでセルロースが容易に 可溶化され，木材の重量も急激に減少することが知られ た. brown rot のこの作用は, hydrolytic といらより はむしろ oxidative なのである.

そこで注目されるのが，ラッカーゼ，パーオキシダー ゼ, チロシナーゼなどの酸化還元酵素である.これらは， フェノールを脱水素してフェノキシラジカルを形成させ, これが重合してリグニン unit を形成するので, リグニ ンの生合成に関連して研究されてきた酵素であるが，条 件によっては脱メチル化反応， $\beta$ ーアリルエーテル結合の 分解などを通してリグニンの分解にも関与することが知 られた(8). リグニンの生分解に関してはまだ不明の点が 多いが，キノコがリグニンを攻撃して芳香族化合物を遊 離し，それを士壤細菌，主として Pseudomonas が酸 化開裂するといら道順が考えられる. 木材質の脱りグニ ンは，セルロース，へミセルロースを利用しやすくする 意義もある.

木材やワラを利用しうるキノコの性質は, これら廃資 源の single cell protein 化にも結びつく. エネルギー 危機以来, 紙, 鋸屃, ワラなどの資源化に関しては, 欧 米で弛みない研究が継続されている. キノコの強力な酸 化還元反応は，モルヒネ系アルカロイドやコレステロー ルの生物変換にも利用されたし, チロシナーゼが食品加 工面でニニークな用途を持つことも知られている.

セルロース, リグニンに次ぐ多糖類で，木材の 15〜 25\%を占るものにへミセルロースがあるが，へミセル ラーゼに関する研究は意外に少ない(9). 木材中のリグニ ンーヘミセルラーゼ結合体の切断は, 木材の再利用に有 効であるとする意見もあるので, へミセルラーゼの研究 は今後の一つの方向であろう.この点に関しては, キノ コはキチナーゼ, ヘミセルラーゼの供給源として再評価 されるべきだと考えている．

キノコの酵素についても, 他の起源の酵素と同じ用途 が考えられるわけであるが，資源の recycle に関連し たセルラーゼ, ヘミセルラーゼ, ラッカーゼなどが今後 は注目されるべきであろう，特に，酸化還元酵素が重要 である. 酵素学の動向は, 固定化酵素から診断酵素, バ
イオリアクターの方向をとっているが，この分野で中心 的役割を担っているのは酸化還元酵素であることを考学 ると, キノコの場合も加水分解酵素から酸化還元酵素へ と考えてよいように思う。

最後に, キノコの酵素生成上の特異点を 2,3 指摘し ておきたいと思う。

キノコは, 生活環の中で monokaryon, dikaryon, diploid の核相を経るが, monokaryon と dikaryon で は子実体形成能力がまったく違う。しかも，子実体の発 生，成熟に伴って酵素組成や活性が大きく変わることが 多数報告されている. また, dikaryon 形成は 2 種類の 不和合性因子（1 種類のものもある）によって支配され ているが，因子の組合せによって酵素活性が違う場合が ある. スエヒロタケの R-glucanase は inducible であ るが，その生成は培地にグルコースの残っている状態で は common-A heterokaryon でのみ見られ, dikaryon, monokaryon, common-B ではほとんど見られない. 培 地中のグルコースが消費されると, dikaryon の Rglucanase 生成は増大するが, monokaryon や common-B では変化がないという.

さらに厄介なことは，振盪培養中に核相が変わる場合 があることである.ナメコでしばしば観察されることで あるが, dikaryon を培養していても monokaryon に 戻ってしまうことがある、これらの点は, キノコの酵素 生産を検討する場合，今後留意されねばならない。

筆者らは，ここ何年かキノコの酵素を調べてきたが， 対象とした菌株はきわめて少ない、それといらのも，キ ノコには分離や培養の困難なものが多いし，子実体を得 なければ分離でさないため，採集の時期も場所も限定ざ れるからである. キノコは未開拓の大分野であるので, 今後の進展に期待されるところが多い. しかし, 日本産 キノコの $1 / 3$ は未だ名前すら付いていないそらであるし， 日本のキノコ学は欧米に比べ胗々たるものである. キノ コの基礎学が進歩しなければ, 系統的なスクリーニング すら拈ぼつかなことを考えると, キノコの基礎学が今 後充実されることが何よりも必要である.士壌の涵養な くして大きな花を咲かせようとするのは，本末転倒もよ いところではないだろらか.

1）宇田川俊一：日菌誌，3，92 (1962).

2) R. G. Benedict: Adv. Appld. Microbiol., 13, 1 (1970).

3）竹内富雄, 飯沼寛信 : 発酵と工業, 34, 843 (1976). 
4）川合正允：発酵と工業，34，834.（1976）

5) 梶 明: 化学子生物, 11, 330 (1973).

6）馬田三夫, 平緒一睍, 木村義夫, 野田国彦 : 農化, 45, 260, 269 (1971).

7) 西沢一俊: 蛋白質核酸酵素, 22, 960 (1977).

8) 原口隆英: 化学亡生物, 14, 626 (1976).

9) R.F.H. Dekker \& G. N. Richards : Adv. Carbohydrate Chem. Biochem., 32, 277 (1976).

（川合 正旮, 協和醊酵工業東京研究所）

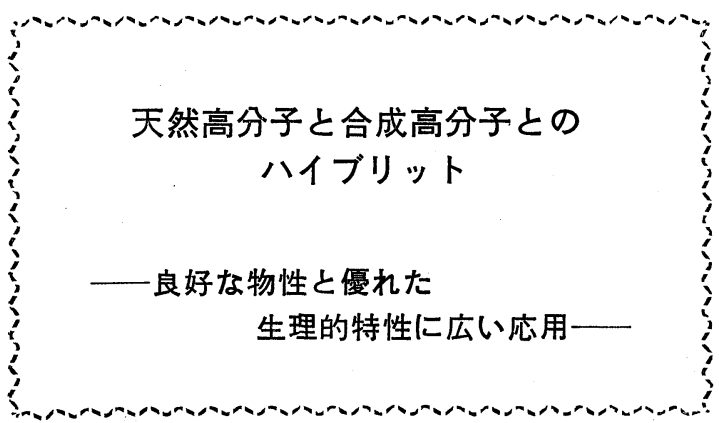

各種の高分子を組合せて複合化することは新しいこと ではない. 用途の開発と複合化の技術進歩が相互に作用 しあって，次々に新材料が出現しているのが現状である. 素材の一方が天然高分子である場合も同じであり, 特に セルローズを中心とした複合材は繊維, フィルム, 成型 物の形で数多く市販されている. しかし，これらの場合， 天然・合成両者の利点を生かすという思想には違いない が, 物理的・化学的性質に重点が㧍かれ, それに加芳て 触感, 美的感覚などの向上を目的とした場合が多く, 天 然高分子, 特に生体高分子の生理的特性を含めての複合 化は，最近になって急激に進歩しはじめたように思われ る.

従来の複合材には, 各種のラミネートフィルム, 混紡, ブレンド成型物などがあり, 特殊なものの一つとして強 化木などがあげられる．また，個々の合成研究としては， セルローズ, 各種のタンパク質に対する各種単量体のグ ラフト重合などが種々の立場で行なわれているが，不安 定な生体高分子の高次構造扣よびそれに基づく微妙な生 理活性まで考学た複合化技術の開発は, 今後の研究の大 きな方向であろう。

医用材料，バイオリアクターなどの応用面を考えても， 生理活性の低下などがない複合化が，また合成高分子の 立場からは生理的機能性の付与される複合化が重要であ る. 天然の素材としては, セルローズ, デンプンその他 の多糖類, ヘパリン, コンドロイチン硫酸などのムコ多
糖類, コラーゲン，ケラチン，アルブミン，グロブリン， 各種の酵素などのタンパク質, その他の生理活性物質な どが考えられ，合成高分子素材としては，ポリエチレン， ポリステレン, シリコン樹脂などの疎水性高分子, ポリ ビニルアルコールなどの非イオン性親水性高分子, ポリ アクリル酸などの高分子電解質など，列記するのに困難 なほどあげることができ，共重合体を加えるとその数は さらに増える。

複合体は，単純ブレンド分散物，グラフト反応などの 反応を伴った分散物, 表面グラフト被覆物, その他種々 の形状があり，天然物と合成物との間の結合様式は，単 なる分子間力, 水素結合力, イオン結合力, 共有結合力 による場合に分けて考えられる、いずれにせよ，生成複 合体は，合成高分子の良好な物性と天然高分子のすぐれ た生理的特性を併せすった材料であることが要求される。 このように，天然高分子と合成高分子のハイブリットは， 素材, 方法, 目的によって多種多様であり，ここで全部 をつくせないので，以下筆者の身近にある数例をあげ責 を果たしたい。

コラーゲンー合成高分子複合体 ${ }^{(1,2)}$ ：コラーゲンは動 物結合組織の主タンパク質で, 分子は 3 本のポリペプチ ド鎖からなる“らせん”を形成しており，分子長は約 $3,000 \AA$, 太さ $15 \AA$, 分子量 30 万の棒状分子である. 分子末端には分子全体の $3 \sim 4 \%$ 当るテロペプタイド 部分があって，この部分で架橋が生じて拈り，通常の条 件では水に不溶性である。このコラーゲンを酵素法ある いはアルカリ法によって処理してテロペプタイド部分を 除去し, 酸性水に可溶化する技術が開発されている. こ のテロペプタイドフリーのコラーゲンは抗原抗体性がほ とんど消失しており，生体に対する親和性が高いため， 医用材料，食品材料として利用されている．ただ，この ものは体内に移植すると，場所によって差はあるが，や がては消化吸収されてしまう，一方，各種の合成高分子 が移植材料として使用されているが，どの移植物でも生 体親和性がなく，とさに拒否反応を特こすこともあり， 抗凝血性その他の生理的特性が不充分であった。 そこで, 合成高分子の安定性とコラーゲンの生体に対するなじみ やすさの組合せが考光られ，たと艺ばコラーゲンとポリ ビニルアルコールの水溶液混合物から透明な複合膜を作 り， $\boldsymbol{r}$ 線照射によって多少の架橋を入れた上，ウサギの 
角膜に移植したところ，この膜は消化をうけず，角膜上 皮細胞が膜上に成長してょく融和した. 簡単なハイブリ ットでも，今までになかった材料となった例である。

筆者の研究グループでは, ポリエチレン, シリコン樹 脂, ポリエステル，ポリビニルアルコールなどの合成高 分子材料表面にコラーゲンを薄層状にひろげ，層状複合 体を作ることを試みている，その方法は次の三工程で完 了する。

i ）合成高分子表面を放電プラズマにより活性化する.

ii） コラーゲン水溶液を所定の厚さに塗布する（1〜 $10 \mu \mathrm{m})$

iii）風乾後, 湿度 $100 \% \mathrm{~N}_{2}$ 中で $\gamma$ 線を照射するか, あるいは紫外線で架橋を入れる.グルタールアルデ ヒドによる化学架橋でもよい.

このようにして作成した人工気管 ${ }^{(3)} は$, 従来の未処理気 管のような離脱はおこらず, 長期間の生存が可能となっ た. スポンジ状, メッシュ状充媜物は, この複合化によ り拒否反応もなく, 繊維芽細胞がよく生育し, 生体内に 長期間存在している.この複合体の表面層はコラーゲン なので，他の生理活性物質，たとえば抗凝血剤へパリン などをイオン結合的に付加してさらに複合化し，抗凝性 表面とすることもできる，また，各種の酵素も簡単に固 定できるなど，その応用の可能性は広く，現在も研究続 行中である. その他，コラーダンと水溶性合成高分子の 複合体は，バイオリアクター用の菌体固定化剂としてる 非常に有効である.

機能性高分子複合体の合成とその応用 ${ }^{(4)}$ ：合成，天 然を問わず，高分子電解質のイオン的相互作用による複 合体の合成についての詳細な検討も行なわれている。 そ の応用領域としては，i）透析膜, 限外濾過膜，ii） マ イクロカプセル材料，iii）電池のセパレーター, iv）水 蒸気を通すプラスチック材, v) 導電性, 带電防止性コ ーティング, vi）環境感知器, 化学検出器, vii）医用 材料などがあげられるが，詳細は原報を参照されたい，

酵素, 菌体の固定 ${ }^{(5)}$ ：生化学反応の連続化, 効率の 向上の目的で, 近年, 酵素, オルガネラあるいは菌体の 固定化が盛んに研究されている. 天然高分子と合成高分 子の複合化が特に応用される分野の一つである. マイル ドな手段によって生理活性を低下させずに固定化するの が一つのポイントと考えられる。詳細は成書を参照され
たい.

以上，とりとめのない記述となったが，天然高分子と 合成高分子とのハイブリットは生態系に执いてさらに広 く応用されるに違いないこのためには，合成高分子の 生態系中に括ける挙動，たとえば微生物による分解，生 体内劣化などについても詳細な研究が必要であるう.

1) 宮田睴夫, 日野常稔: 表面, 10, 82 (1972).

2) Y.Shimizu, R. Abe, T. Teramatsu, S. Okamura \& T. Hino : Biomat. Med.Dev., Art.Org., 5(1), 49-66 (1977).

3) 阿倍隆二, 寺松孝, 秋山太一郎 : 人工臓器, 2, 6 (1973).

4）中島章夫 : 表面, 14, 508 (1976).

5）千畑一郎編：“固定化酵素”，講談社， 1975.

（日野 常稔, 生産開発科学研究所）

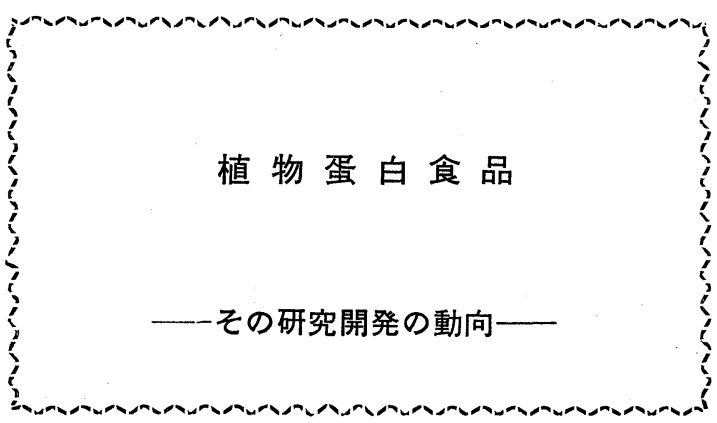

世界的な経済海域専有時代の幕明けは，大豆や小麦の 蛋白質を加工してつくったいわゆる植物蛋白食品の需要 に過熱状態をもたらした，明日使う原料魚が十分に入手 できないカマボコ屋は，それに代る蛋白素材として植物 蛋白質に熱い目を向ける，品質は落ちるが値段でカバー しょう，200 海里時代を迎えて消費者もがまんしてくれ るだろう，等々、だが，はたしてこのように植物蛋白メ 一カーやカマボコ屋の思い通りに事は運ぶであろらか.

大半の動物性蛋白食品を実質的には輸入に頼っている わが国が，資源不足を解消する手段として植物蛋白食品 を考える場合，豆腐に代表されるような伝統的植物蛋白 食品をもっと多用すればよい, という議論が常にでてく る.筋としては確かに一理はあるが，これは現実的でな い. 戦後の食生活パターンの著しい変化を考学るならば, この伝統的な植物蛋白食品の再認識と並んで, さらに多 種類の現代的食品に形を借りることが必要である．言い 換えれば，水産練製品の代替原料とするのも結構である し, 畜肉大豆混合ソーセージや大豆牛乳, 植物蛋白入り チーズなど，今市場にあるすべての食品の蛋白質部分を 植物蛋白食品で置き換える努力が肝要であるう. 
油糧種子蛋白質の食用化を主題とした，世界で初めて の国際シンポジウムが山中湖畔で開かれたのは，今から 13 年前のことである. 開催地に日本を選んだ第一の理 由は，大豆を食べる習慣を持つ唯一の先進国日本から， 植物蛋白食用化の具体的ヒントを得ようということにあ った、その願いは，残念ながら直接的な実を結ぶには至 らなかったが，このシンポジウムは逆に二つの大きな賜 り物をわが国に残してくれた。一つは，わが国の伝統的 大豆食品の製造過程を本格的に解明しようとする気運で あり，他の一つは，植物蛋白質のもつ functionality（機 能特性）を積極的に利用しようとする姿勢であった。

まず第一の点に関しては, 豆腐, 凍豆腐, 湯葉, 油揚 げなどについて，その後目ざましい研究成果が得られて いる. 中でも，原料大至の性状を含めて，最終製品の品 質を支配する因子の解明に手がかりを与えた豆腐製造過 程に関する研究の意義は大きい，この一連の研究は，伝 統的大豆食品の製造工程を合理化するための資料を提供 するとともに，これら食品の製造法にヒントを得た新し い蛋白素材製造の可能性をも示した．たとえば，凍豆腐 のスポンジ状組織形成機構の解明から, 凍結変性を利用 した組織状大豆蛋白食品, すなわち一種の人工肉をつく る新しい方式が考えられたり，湯葉膜生成機棈研究の結 果から新しい可食被膜の製法に関するヒントが得られた り, 今後の発展が期待されるいくつかの実験室的な成果 が生まれている.

第二の functionality を利用する姿勢とは，植物蛋白 が潜在的に持っている物理的特性，たとえば乳化性，起 泡性，保水性，結着性，あるいはゲルや繊維を形成する ような functionalityを，他の食品に有效に活用しよう ということである. 現在各国で行なわれている研究開発 も，大体この線上にあると見てよい.このような研究開 発の方向は原則的に二つに大別される. 一つは植物蛋白 質を添加剤的に少量使用する用法であり，他は植物蛋白 質を主要素材として大量に使用するものである．実際に は前者の製品開発が先行したが，食品という枓の中でひ き出しうる蛋白質の functionality には自ら限界があり， 特効薬的な効果は元来無理な期待であった. しかし，ソ 一セージなどの畜肉加工製品の脂肪や水分の分離防止, あるいは製菓・製パンの分野で卵や乳製品の一部代替と いら形で大豆蛋白質が使用されているのも事実である.
一方，植物蛋白質を主要素材とする場合には，既存の 食品と異なる独創的な食品を目ざす行き方と，すでにあ る食品のどれかをモデルに，その形を借りる行き方の二 通りがある，わが国では，開発の当初から前者に固執す る動きが底流として根強く続いてきた. 確かに, イミテ ーション, 代用品というイメージは悪く, またたえず本 物の值動きにふりまわされる. しかし, 保守性の強い食 品選択の本質をよく見きわめれば，新素材がある社会の 食パターンの中にとり込まれる現実的な方法として, た とえそれがどのような欠点を持っていようとも, 後者の 方法しかありえない，基礎的な研究面は別として，大豆 蛋白質の新しい食用化を常に先導し, 消費量でもわが国 をはるかにリードしているアメリカは，この点をよく見 透した研究開発に終始している. 最近は, わが国でもこ のような現実的な手法が少しずつ実を結ぶ兆が見党てき て扣り，今後の展開が大いに期待される。

最後に, 植物蛋白食品の研究開発の問題点について少 し触れて拉きたい，まず，新しい食品素材がその座を占 めるためには，嗜好的な閾を乗り越えることが前提条件 となる. 現在の植物蛋白食品はまだこの間を越せずにい る. そして, その最も共通的な品質上の弱点は, 開発当 初から未だに続いているフレーバーの問題である. 伝統 的大豆食品以外では, 穀物臭や大豆臭として製品に残る. 臭いはほとんどマイナス因子として作用するが，低コス トでこの点を解決する現実的な手段はなかなか見いださ れない,もし, このオフ・フレーバーが今より軽減され。 れば、混用しうる食品の種類や混合比率は確実に増すこ とになる、また, 現在の品質および価格のバランスから 見て, 植物蛋白食品は今後当分の間, 加工用ないしは業 務用が主流をなすであろらし，その用法も既存食品への 混用といら形をとらざるをえないだろう，その意味から。 調理, 加工中に他の食品素材との間に起こる相互反応や 変化に関する情報がもっと必要となる. 一方, 研究開発 を進める上での問題点は, 基礎的あるいは実験室的な研 究結果を, より効果的に現実の利用開発と結びつけるに はどうしたらよいかといら点である. この解決には二つ. の可能性がある. 一つは学問的興味よりも市場の要請を 優先させたテーマの選び方であり, もら一つは, ばらば らに行なわれる基礎的ないしは実験室的研究の成果と実 際の製品化とを結びつける機能を, 従来の枠にとらわれ 
ずに何らかの形で組織化することであろう.

人類の蛋白不足解消の一端を荷う植物蛋白食品は, は たしてどのような形で我々の食生活の中に定着するであ ろらか. 今, 具体的に想像できる唯一の姿は, バターに 対するマーガリンのそれである.そして，その段階まで
到達しうるか否かは，既存の食品に対する模倣と混合と を, いかに謙虚に, かつ合理的, 組織的に行なえるかど らかにかかっている。

（青木 宏, 大妻女子大学）

\section{FAOB 第一回会議のお知らせ}

$\mathrm{FAOB}$ (アジア，オセアニア地域生化学者連合）第一回会 議 (会頭：八木国夫名大教授) が FAOB, IUB (国際生化学 連合）ならびに日本生化学会の後援の下に下記の要領で開催 されます。

日 時: 1977 年 10 月 10 日 12 日

場 所：名古屋観光ホテル 名古屋市中区錦一(052-2317711)

会議予定：

\begin{tabular}{|c|c|c|c|}
\hline 月 日 & 午 & 午 & 刻 \\
\hline 10月 10 日 & 登 録 & 登 録 & $\begin{array}{l}\text { 開 会 式 } \\
\text { 総 会 講 演 } \\
\text { レセプション }\end{array}$ \\
\hline 10月11日 & シソポジウムA & シソポジウムA & 特別 講 演 \\
\hline & $\begin{array}{l}\text { シソポジウムB } \\
\text { 一 般 講 演 }\end{array}$ & $\begin{array}{l}\text { シソポジウム } \mathrm{B} \\
\text { 一 般 講 演 }\end{array}$ & \\
\hline 10月12日 & $\begin{array}{l}\text { シソポジウムA } \\
\text { シソポジウム } \mathrm{B} \\
\text { 一 般 講 演 }\end{array}$ & $\begin{array}{l}\text { シソポジウムA } \\
\text { シンポジウム } \mathrm{B} \\
\text { 一 般 講 演 }\end{array}$ & \\
\hline
\end{tabular}

総会講演：

B. Pullman(Paris) Quantum-mechanical Exploration of the Role of Water and Cations in Biological Systems.

K. Yagi (Nagoya) Flavoprotein Catalysis.

特別講演:

H. Neurath (Seattle) Structure, Function and Evolution of Proteases.

シンポジウムA : BIOCHEMICAL ASPECTS OF NUTRITION

\section{Proteins}

F. J. Ballard (Adelaide), P. N. Campbell (London), H. N. Munro (Cambridge), R. T. Schimke (Stanford), A.-N. Radhakrishnan (Hyderabad), T. Murachi(Kyoto)

Lipid and Carbohydrate

F. Lynen (München), S. Numa (Kyoto), J. Ganguly (Bangalore), W. J. Whelan (Miami), G. Semenza (Zürich)

\section{Vitamin}

H. R. Cama (Bangalore), H.F. DeLuca (Madison), J. Stenflo (Malmö), Y. Nose (Kyoto), J. Okuda (Nagoya), K. T. Yasunobu (Honolulu), K. Fujii and F. M. Huennekens (La Jolla), O. Hayaishi (Kyoto)

\section{シンポジウムB : STRUCTURE AND FUNCTION OF} BIOMEMBRANES

\section{Membrane Structure}

G. K. Radda (Oxford), W. Stoffel (Köln), S. Ji (Dortmund)

Assembly and Biogenesis

W. Linnane (Clayton), T. Omura (Fukuoka)

Energy Transduction

E. C. Slater (Amsterdam), Y. Hatefi (La Jolla), F. Gibson (Canberra), P. C. Hinkle (Ithaca), Y. Kagawa (Tochigi), M. Avron (Stanford), T.E. King (Albany)

Cell Surface and Biological Function

H. M. Kalckar (Boston), E. H. Eylar (Toronto),

N. Sharon (Rehovoth), G. Ashwell (Bethesda), J. L. Strominger (Cambridge), D. A. Lowther (Clayton)

一般講演:

シンポジウムAに関係の深いfree paper 48 題が別の会場で ロ頭発表されます.

\section{登録ならびに登録料 :}

本会議に出席御希望の方は 2 nd circular に添付の Form B に必要事項を御記入の上，事務局（村地孝京大教授，京都市 左京区聖護院河原町 京都大学医学部附属病院中央検査部) 宛 御送付下さい.

登録料は 18,000 円. 本会議の抄録集の費用, レセプショ ンの会費を含んでいます.

2nd Circular 請求先 :

113 東京都文京区弥生 2-4-16 学会センタービル内 日本生化学会 Tel. 03-815-1913 